\title{
Evaluating the Effectiveness of Mulching for Reducing Soil Erosion in Cut Slope and Fill Slope of Forest Roads in Hyrcanian Forests
}

\author{
Ahmad Solgi, Ramin Naghdi, Eric K. Zenner, Vahid Hemmati, \\ Farshad Keivan Behjou, Ali Masumian
}

\begin{abstract}
Forest operations often enhance runoff and soil loss in roads and skid trails, where cut slopes and fill slopes are the most important source of sediment. This study evaluated the effectiveness of four erosion control treatments applied to cut slope and fill slope segments of forest roads of different ages in the Hyrcanian forest in northern Iran. The treatment combinations, each replicated three times, included four classes of mulch cover (bare soil [BS], wood chips cover [WCH], sawdust cover [SC], and rice straw cover [RSC]), two levels of side slope (cut slope and fill slope), two levels of side slope gradient (20-25\% and 40-45\%), and three levels of road age (three, 10 and 20 years after construction). Mulch cover treatments significantly reduced average surface runoff volume and sediment yield compared to BS. Regardless of erosion control treatment, greater surface runoff volume and soil loss under natural rainfall occurred on steeper slope gradients in all road age classes and decreased with increasing road age on both slope gradients. On cut slopes, average runoff and soil loss from the plots covered with WCH (17.63 l per plot, $2.43 \mathrm{~g} \mathrm{~m}^{-2}$ ) was lower than from those covered with SC (22.81 l per plot, $\left.3.50 \mathrm{~g} \mathrm{~m}^{-2}\right)$, which was lower than from those covered with RSC (29.13 l per plot, $4.41 \mathrm{~g} \mathrm{~m}^{-2}$ and BS (34.61 l per plot, $\left.4.94 \mathrm{~g} \mathrm{~m}^{-2}\right)$. On fill slopes, average runoff and soil loss from the plots covered with WCH (14.13 l per plot, $1.99 \mathrm{~g} \mathrm{~m}^{-2}$ ) was lower than from plots covered with SC (20.01 l per plot, $3.23 \mathrm{~g} \mathrm{~m}^{-2}$ ), which was lower than from plots covered with RSC (24.52 l per plot, $4.06 \mathrm{~g} \mathrm{~m}^{-2}$ ) and BS (29.03 l per plot, $4.47 \mathrm{~g} \mathrm{~m}^{-2}$ ). Surface cover successfully controlled erosion losses following road construction, particularly on steep side slopes with high erosion potential.
\end{abstract}

Keywords: rice straw, sawdust, sediment yield, soil loss, woody chips

\section{Introduction}

Forest roads and skid trails can significantly increase surface runoff and sediment yield, especially when bare soils are exposed to high traffic frequency or when the bearing capacity of the soil is exceeded and rutting occurs (Swift and Burns 1999, McBroom et al. 2008, Solgi et al. 2014). As forest roads constitute the basic infrastructure for forest management activities (Hacisalihoğlu et al. 2019), potential environmental problems, such as increased surface runoff and soil erosion following heavy rainfall (Ziegler et al. 2004) that arise following forest road construction and use mandate, require protective measures that are either considered during the planning stage or suitable techniques are implemented in the field during or after the harvesting operation.

One of the main impacts of forest road construction is the formation of steep, bare roadside slopes (Liu et al. 2014, Cerdà 2007). Lack of protective surface cover and bare roadside slopes can generate significant amounts of soil loss during the rainy season (Arnáez et al. 2004, Jordán-López et al. 2009, Bochet et al. 2009). Once severely degraded, poor soil conditions make natural restoration of ground cover vegetation on roadside slopes quite difficult (Bochet and GarcíaFayos 2004). To prevent or at least reduce surface runoff and roadside slope erosion, the use of soil protective 
mats of varying composition has been shown to be an effective countermeasure (Cerdà 2007, Bochet et al. 2009). For example, grass cover and grass mulch effectively reduced surface runoff and erosion over bare control plots ( $\mathrm{Li}$ et al. 2011), while on roadside cut slopes vegetated roadside slopes reduced soil erosion by a factor of 30 compared to non-vegetated slopes (Cerdà 2007). In the northern mountainous forests of Iran, jute and mulch cover are promising techniques for reducing soil erosion in cut slopes, but road age was another key factor affecting soil erosion on roadside slopes (Lotfalian et al. 2019).

While amounts of soil loss can vary significantly among controls, fill slopes, and cut slopes, the slope gradient, roughness coefficient, and vegetation cover are also important factors. Using a rainfall simulator to study the effects of vegetation on runoff, sediment and soil shear strength on road trenches in China revealed that soil erosion on cut slopes exceeded that of fill slopes (Shao et al. 2014). Similarly, soil loss was 43\% greater in cut slopes than fill slopes and 2.5 times greater than in control areas in a study in Turkey, but also depended on the slope gradient and its length (Hacisalihoğlu et al. 2019).

The objectives of this study were:

$\Rightarrow$ to evaluate and quantify the mitigating effects of soil protective mats on surface runoff and soil loss following road construction

$\Rightarrow$ to contrast these effects among cut slopes, fill slopes, and a control area

$\Rightarrow$ to evaluate the effects of road age on surface runoff and soil loss.

\section{Materials and Methods}

\subsection{Site Description}

This research was conducted in the Shenrood forest, Guilan province, northern Iran $\left(36^{\circ} 13^{\prime} \mathrm{N}\right.$ and $36^{\circ} 15^{\prime} \mathrm{N}$ and $53^{\circ} 10^{\prime} \mathrm{E}$ and $53^{\circ} 15^{\prime}$ E) between November 2015 and January 2016. Oriental beech (Fagus orientalis Lipsky) and common hornbeam (Carpinus betulus) are the dominant species, with canopy cover of $81 \%$ (Site 1), $84 \%$ (Site 2), and 79\% (Site 3). Herbaceous species in the forest are Carex sylvatica, Buxus hyrcana, Berachypodium silvaticum, Ruscus hyrcanus, Phyllitis scolopendrium and Polypodium auidinum. The area is characterized by brown forest soils formed on unconsolidated limestone with a moderately deep profile. Soils are classified as Eutric Cambisols (FAO/ UNESCO 1990) and Typic Eutrudepts (USDA Soil Taxonomy 1998). Soil textures based on particle size analysis using the Bouyoucos hydrometer method
(Kalra and Maynard 1991) were classified as clay loam. The elevations of the three study sites were approximately 950-1200 m above sea level with a northerly aspect. Based on historic weather data of the previous 50 years, the average annual rainfall recorded at the closest (20 km distant) national weather station is $1210 \mathrm{~mm}$, with a maximum mean monthly rainfall of $145 \mathrm{~mm}$ in October and a minimum rainfall of $25 \mathrm{~mm}$ in August. The mean annual temperature is $16^{\circ} \mathrm{C}$, with the lowest temperatures in February.

\subsection{Experimental Design and Data Collection}

A three-year-old (Site 1) and two older (10 and 20 years old, Sites 2 and 3) bare forest roads with nonstabilized fill slopes and cut slopes on two slope classes (20-25\% and $40-45 \%)$ were selected for this study. The cut slope, created by excavation into natural hill slopes, was steeper than the natural slope. The fill slope was the slope of unconsolidated excavated material that was pushed below the road; it was also steeper than the natural slope. The length of the existing road network is $9.6 \mathrm{~km}$ (Site 1), $12.4 \mathrm{~km}$ (Site 2) and $13.1 \mathrm{~km}$ (Site 3). The general aspect of all three areas is towards the north. The slope class of $0-30 \%$ encompassed $63.7 \%$ of Site $1,71.8 \%$ of Site 2 and $75.6 \%$ of Site 3. For soil cover, four types of soil protective mats were investigated: sawdust mulch cover (SC, produced from oriental beech and common hornbeam trees and obtained from a sawmill near the study Site), rice straw cover (RSC, average length of 3-15 cm and straw thickness of $0.3-0.5 \mathrm{~mm}$ ), wood chips cover $(\mathrm{WCH}$, average width, length, and thickness of $1.2 \mathrm{~cm}, 15 \mathrm{~cm}$, and $0.2 \mathrm{~cm}$, respectively), and bare soil (BS). Sawdust $\left(5.7 \mathrm{~kg} \mathrm{~m}^{-2}\right)$, straw $\left(2.6 \mathrm{~kg} \mathrm{~m}^{-2}\right)$ and wood chips $\left(12.8 \mathrm{~kg} \mathrm{~m}^{-2}\right)$ were applied at a rate that initially gave $100 \%$ coverage (thickness of $1 \mathrm{~cm}$ ) (Fernández and Vega 2016). A total of 72 runoff plots were installed that included 24 combinations of four levels of mat cover (M), two levels of road slope (cut slope and fill slope) (S), and three levels of road age $(3,10$, and 20 years) $(A)$, each replicated three times $(4 \mathrm{M} \times 2 \mathrm{~S} \times 3 \mathrm{~A} \times 3$ plots $)$.

The size of each treatment plot was $2 \mathrm{~m}$ long by $1 \mathrm{~m}$ wide, with a minimum of $2 \mathrm{~m}$ distance between plots. Treatment plots were surrounded by $30 \mathrm{~cm}$ tall wooden boards that were inserted to a depth of $10 \mathrm{~cm}$ into the soil to control surface water movement from the inside to the outside of the plot area and vice-versa (Solgi et al. 2014). A collection made of a metal sheet and covered with plastic or sheet metal was positioned at the downslope end of the plot and prevented the direct entry of rainfall. A funnel type structure was constructed on the lower side of each plot to collect all 
surface water runoff from inside the area in a tank with 50 liter capacity (Fig. 1).

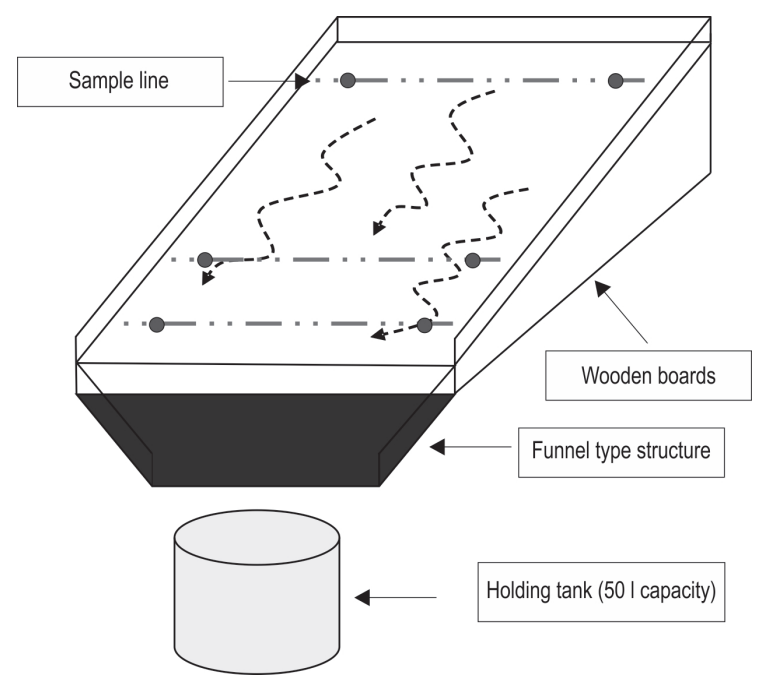

Fig. 1 Layout of sample areas
Volume of surface runoff was calculated after each of the 7 rainfall events by measuring the height of the water in the collecting tanks. After a thorough mixing to bring all the sediments collected in a 1 liter subsample from the collected runoff material into suspension, the sediment concentration in each plot was determined (Sadeghi et al. 2007). The sample was taken to the laboratory where the sediment was filtered, oven-dried at $105^{\circ} \mathrm{C}$ for a day and weighed (drying and weighing method). Runoff volume and sediment loss from each plot were computed for each rainfall event, after which tanks were emptied and cleaned.

In each plot, five sample lines were delineated perpendicular to the trail with a $0.4 \mathrm{~m}$ buffer zone between lines to avoid interactions. Three of the five lines were randomly selected for the measurement of the soil physical properties. Soil samples were collected at different locations: the left side (LS) and the right side (RS) of each line (Fig. 1).

Table 1 Physical soil characteristics in experimental plots by (bare soil [BS], rice straw cover [RSC], straw mulch [SC], and wood chips [WCH]), slope gradient (20-25\% and 40-45\%) and side slope type (cut slope and fill slope)

\begin{tabular}{|c|c|c|c|c|c|c|c|c|c|c|}
\hline \multirow{3}{*}{$\begin{array}{l}\text { Road } \\
\text { age }\end{array}$} & \multirow{3}{*}{ Side slope } & \multirow{3}{*}{ Parameter } & \multicolumn{4}{|c|}{ Slope, $20-25 \%$} & \multicolumn{4}{|c|}{ Slope, $40-45 \%$} \\
\hline & & & \multicolumn{4}{|c|}{ Mulch type } & \multicolumn{4}{|c|}{ Mulch type } \\
\hline & & & BS & $\mathrm{RSC}$ & SC & WCH & $\mathrm{BS}$ & $\mathrm{RSC}$ & SC & WCH \\
\hline \multirow{8}{*}{3} & \multirow{4}{*}{ Cut slope } & $\mathrm{DB}, \mathrm{g} \mathrm{cm}^{-3}$ & $1.27^{\mathrm{a}}$ & $1.29^{\mathrm{a}}$ & $1.26^{\mathrm{a}}$ & $1.32^{\mathrm{a}}$ & $1.35^{\mathrm{a}}$ & $1.30^{\mathrm{a}}$ & $1.33^{\mathrm{a}}$ & $1.32^{\mathrm{a}}$ \\
\hline & & Sand, $\%$ & $43^{a}$ & $40^{a}$ & $39^{a}$ & $41^{\mathrm{a}}$ & $41^{a}$ & $39^{a}$ & $43^{a}$ & $42^{a}$ \\
\hline & & Silt, \% & $25^{\mathrm{a}}$ & $26^{a}$ & $29^{a}$ & $30^{\mathrm{a}}$ & $24^{a}$ & $29^{a}$ & $27^{\mathrm{a}}$ & $24^{\mathrm{a}}$ \\
\hline & & Clay, \% & $32^{\mathrm{a}}$ & $34^{\mathrm{a}}$ & $32^{a}$ & $29^{a}$ & $35^{a}$ & $32^{a}$ & $30^{a}$ & $34^{a}$ \\
\hline & \multirow{4}{*}{ Fill slope } & $\mathrm{DB}, \mathrm{g} \mathrm{cm}^{-3}$ & $1.29^{a}$ & $1.3^{a}$ & $1.28^{\mathrm{a}}$ & $1.35^{\mathrm{a}}$ & $1.32^{\mathrm{a}}$ & $1.31^{\mathrm{a}}$ & $1.29^{\mathrm{a}}$ & $1.32^{\mathrm{a}}$ \\
\hline & & Sand, $\%$ & $37^{a}$ & $37^{a}$ & $40^{a}$ & $39^{a}$ & $38^{a}$ & $39^{a}$ & $37^{a}$ & $40^{a}$ \\
\hline & & Silt, $\%$ & $31^{\text {a }}$ & $29^{a}$ & $28^{\mathrm{a}}$ & $29^{\mathrm{a}}$ & $26^{\mathrm{a}}$ & $28^{\mathrm{a}}$ & $28^{\mathrm{a}}$ & $27^{\mathrm{a}}$ \\
\hline & & Clay, \% & $32^{\mathrm{a}}$ & $34^{a}$ & $32^{a}$ & $32^{a}$ & $36^{a}$ & $33^{a}$ & $35^{a}$ & $33^{a}$ \\
\hline \multirow{8}{*}{10} & \multirow{4}{*}{ Cut slope } & $\mathrm{DB}, \mathrm{g} \mathrm{cm}^{-3}$ & $1.20^{\mathrm{a}}$ & $1.16^{a}$ & $1.15^{a}$ & $1.18^{a}$ & $1.19^{a}$ & $1.23^{\mathrm{a}}$ & $1.17^{a}$ & $1.20^{\mathrm{a}}$ \\
\hline & & Sand, \% & $37^{a}$ & $39^{a}$ & $38^{a}$ & $38^{a}$ & $36^{a}$ & $38^{a}$ & $39^{a}$ & $38^{\mathrm{a}}$ \\
\hline & & Silt, \% & $24^{\mathrm{a}}$ & $23^{\mathrm{a}}$ & $22^{\mathrm{a}}$ & $26^{\mathrm{a}}$ & $24^{\mathrm{a}}$ & $23^{\mathrm{a}}$ & $23^{\mathrm{a}}$ & $22^{\mathrm{a}}$ \\
\hline & & Clay, $\%$ & $39^{a}$ & $38^{a}$ & $40^{\mathrm{a}}$ & $36^{a}$ & $40^{a}$ & $39^{a}$ & $38^{a}$ & $40^{a}$ \\
\hline & \multirow{4}{*}{ Fill slope } & $\mathrm{DB}, \mathrm{g} \mathrm{cm}^{-3}$ & $1.16^{\mathrm{a}}$ & $1.15^{\mathrm{a}}$ & $1.19^{a}$ & $1.21^{\mathrm{a}}$ & $1.20^{\mathrm{a}}$ & $1.17^{\mathrm{a}}$ & $1.16^{a}$ & $1.19^{a}$ \\
\hline & & Sand, \% & $42^{a}$ & $40^{\mathrm{a}}$ & $39^{a}$ & $41^{\mathrm{a}}$ & $41^{\mathrm{a}}$ & $39^{a}$ & $43^{a}$ & $40^{\mathrm{a}}$ \\
\hline & & Silt, $\%$ & $23^{a}$ & $24^{\mathrm{a}}$ & $25^{\mathrm{a}}$ & $24^{a}$ & $22^{\mathrm{a}}$ & $23^{a}$ & $21^{\mathrm{a}}$ & $24^{a}$ \\
\hline & & Clay, \% & $35^{a}$ & $36^{a}$ & $36^{a}$ & $35^{a}$ & $37^{a}$ & $38^{a}$ & $36^{a}$ & $36^{a}$ \\
\hline \multirow{8}{*}{20} & \multirow{4}{*}{ Cut slope } & $\mathrm{DB}, \mathrm{g} \mathrm{cm}^{-3}$ & $1.05^{\mathrm{a}}$ & $1.01^{\mathrm{a}}$ & $1.03^{\mathrm{a}}$ & $1.08^{\mathrm{a}}$ & $1.07^{\mathrm{a}}$ & $1.08^{\mathrm{a}}$ & $1.04^{\mathrm{a}}$ & $1.05^{\mathrm{a}}$ \\
\hline & & Sand, \% & $45^{a}$ & $44^{\mathrm{a}}$ & $44^{a}$ & $47^{a}$ & $46^{a}$ & $46^{a}$ & $49^{a}$ & $48^{a}$ \\
\hline & & Silt, \% & $16^{a}$ & $17^{\mathrm{a}}$ & $19^{a}$ & $19^{a}$ & $18^{a}$ & $20^{\mathrm{a}}$ & $16^{a}$ & $21^{\mathrm{a}}$ \\
\hline & & Clay, \% & $39^{a}$ & $39^{a}$ & $37^{a}$ & $36^{a}$ & $36^{a}$ & $34^{a}$ & $35^{a}$ & $31^{a}$ \\
\hline & \multirow{4}{*}{ Fill slope } & $\mathrm{DB}, \mathrm{g} \mathrm{cm}^{-3}$ & $0.98^{\mathrm{a}}$ & $1.03^{\mathrm{a}}$ & $0.99^{a}$ & $1.02^{\mathrm{a}}$ & $0.95^{\mathrm{a}}$ & $1.02^{\mathrm{a}}$ & $0.99^{\mathrm{a}}$ & $1.01^{\mathrm{a}}$ \\
\hline & & Sand, \% & $43^{a}$ & $44^{a}$ & $49^{a}$ & $43^{a}$ & $44^{a}$ & $46^{a}$ & $48^{a}$ & $45^{a}$ \\
\hline & & Silt, \% & $20^{a}$ & $19^{a}$ & $16^{a}$ & $19^{a}$ & $18^{a}$ & $17^{a}$ & $15^{a}$ & $19^{a}$ \\
\hline & & Clay, \% & $37^{\mathrm{a}}$ & $37^{\mathrm{a}}$ & $35^{\mathrm{a}}$ & $38^{a}$ & $38^{a}$ & $37^{a}$ & $37^{\mathrm{a}}$ & $36^{a}$ \\
\hline
\end{tabular}

Different superscript letters across a row indicate a statistical difference among treatments at alpha $=0.05$ 
Soil samples that weighed on average $338 \mathrm{~g}$ were collected with a $196.25 \mathrm{~cm}^{3}$ (inside diameter $5 \mathrm{~cm}$, length $10 \mathrm{~cm}$ ) cylinder outside and immediately to the left of each plot. Soil samples were oven dried at $105^{\circ} \mathrm{C}$ to constant mass $(24 \mathrm{~h})$, after which the water content was measured gravimetrically (Kalra and Maynard 1991).

Dry soil bulk density $\left(D_{\mathrm{b}}, \mathrm{g} \mathrm{cm}^{-3}\right)$ was computed as Equation (1):

$$
D_{\mathrm{b}}=W_{\mathrm{d}} / V_{\mathrm{C}}
$$

Where:

$W_{\mathrm{d}}$ is the weight of dry soil, $\mathrm{g}$

$V_{\mathrm{C}}$ is the volume of soil cores, $196.25 \mathrm{~cm}^{3}$.

\subsection{Statistical Analysis}

Three-way ANOVA was used to test for significant differences in $D_{\mathrm{b}}$, runoff volume, and soil loss in all treatment combinations and interactions of the main factors. Tukey's HSD test was used to determine which combinations of cover type, side slope class, and road age class differed statistically significantly from each other and from controls at an overall $\alpha$-level of 0.05 . The SPSS software version 11.5 was used for all statistical analyses (Zar 1999).

\section{Results}

Dry bulk density $\left(D_{\mathrm{b}}\right)$ and soil texture did not differ significantly among plots designed for different treatment combinations (Table 1).

Average surface runoff volume (range: 2.66$29.361 \mathrm{~m}^{-2}$ ) was significantly affected by the main effects, the two-way interactions of road age $\times$ slope gradient, road age $\times$ mulch type, and slope gradient $\times$ mulch type (Table 2). Similarly, average soil loss (range: $1.10-6.61 \mathrm{~g} \mathrm{~m}^{-2}$ ) was significantly affected by the main effects, the two-way interactions of road age $\times$ slope gradient, road age $\times$ mulch type, slope gradient $\times$ mulch type, and the three-way interactions of road age $\times$ side slope $\times$ slope gradient and road age $\times$ soil gradient $\times$ mulch type (Table 2 ).

Under natural rainfall conditions, average surface runoff volume and soil loss depended strongly on the type of side slope, increased with increasing slope gradient in all road age classes, and decreased consistently with increasing road age on both slope gradients (Tables 3 and 4).

Average surface runoff volume and soil loss were 1.21 and 1.11 times greater on cut slopes than on fill slopes, respectively (Table 5 and 6).

Compared to surface runoff volumes $\left(15.921 \mathrm{~m}^{-2}\right)$ and sediment yields $\left(4.70 \mathrm{~g} \mathrm{~m}^{-2}\right)$ on bare forest soil
Table 2 Analysis of variance ( $P$-values) of effects of road age, side slope type, slope gradient and mulch type on surface runoff and soil loss

\begin{tabular}{|l|c|r|r|}
\hline \multirow{2}{*}{ Source of variable } & \multirow{2}{*}{ d.f. } & \multicolumn{2}{|c|}{$P$-values } \\
\cline { 3 - 4 } & & \multicolumn{1}{|c|}{ Runoff } & Soil loss \\
\hline Road age & 2 & $\leq 0.001$ & $\leq 0.001$ \\
\hline Side slope & 1 & $\leq 0.001$ & $\leq 0.001$ \\
\hline Slope gradient & 1 & $\leq 0.001$ & $\leq 0.001$ \\
\hline Mulch & 3 & $\leq 0.001$ & $\leq 0.001$ \\
\hline Road age $\times$ Side slope & 2 & 0.774 & 0.017 \\
\hline Road age $\times$ Slope gradient & 2 & 0.010 & 0.590 \\
\hline Road age $\times$ Mulch & 6 & $\leq 0.001$ & $\leq 0.001$ \\
\hline Side slope $\times$ Slope gradient & 1 & 0.180 & 0.069 \\
\hline Side slope $\times$ Mulch & 3 & 0.809 & 0.166 \\
\hline Slope gradient $\times$ Mulch & 3 & 0.005 & $\leq 0.001$ \\
\hline Road age $\times$ Side slope $\times$ Slope gradient & 2 & 0.966 & 0.003 \\
\hline Road age $\times$ Side slope $\times$ Mulch & 6 & 0.881 & 0.753 \\
\hline Road age $\times$ Slope gradient $\times$ Mulch & 6 & 0.999 & 0.922 \\
\hline Side slope $\times$ Slope gradient $\times$ Mulch & 3 & 0.990 & 0.586 \\
\hline Road age $\times$ Side slope $\times$ Slope gradient \\
$\times$ Mulch & 6 & 0.999 & 0.409 \\
\hline$P$-vales less + ton 0.05 are 9 iven in bold & & & \\
\hline
\end{tabular}

$P$-values less than 0.05 are given in bold

(controls), all mulch cover treatments yielded significant reductions (Table 3 and 4). On cut slopes, average runoff and soil loss were significantly less in plots covered with wood chips $(\mathrm{WCH})\left(8.83 \mathrm{l} \mathrm{m}^{-2}, 2.44 \mathrm{~g} \mathrm{~m}^{-2}\right)$ than in those covered with sawdust (SC) $\left(12.241 \mathrm{~m}^{-2}\right.$, $3.50 \mathrm{~g} \mathrm{~m}^{-2}$ ), and both were less than in those covered with rice straw (RSC) $\left(14.52 \mathrm{l} \mathrm{m}^{-2}, 4.41 \mathrm{~g} \mathrm{~m}^{-2}\right)$. Average runoff volume and soil loss on BS $\left(17.31 \mathrm{l} \mathrm{m}^{-2}, 4.94 \mathrm{~g} \mathrm{~m}^{-2}\right)$ were significantly greater than on all other mulch types. On cut slopes, mulch cover treatments thus reduced runoff volumes and sediment yields over BS, with reductions of 49 and 51\% (WCH), 30 and 29\% (SC), and 16 and 11\% (RSC), respectively (Fig. 2).

On fill slopes average runoff and soil loss were significantly less in plots covered with WCH $\left(7.07 \mathrm{l} \mathrm{m}^{-2}\right.$, $\left.2.00 \mathrm{~g} \mathrm{~m}^{-2}\right)$ than in those covered with SC $\left(10.05 \mathrm{l} \mathrm{m}^{-2}\right.$, $3.23 \mathrm{~g} \mathrm{~m}^{-2}$ ), and both were significantly less than in plots covered with RSC $\left(12.23 \mathrm{l} \mathrm{m}^{-2}, 4.06 \mathrm{~g} \mathrm{~m}^{-2}\right)$. Average runoff volume and soil loss on BS $\left(14.52 \mathrm{l} \mathrm{m}^{-2}, 4.47 \mathrm{~g} \mathrm{~m}^{-2}\right)$ were significantly greater than on all other mulch types. On fill slopes, mulch cover treatments reduced runoff volumes and sediment yields over BS, with reductions of 51 and $55 \%(\mathrm{WCH}), 31$ and $28 \%$ (SC), and 16 and $9 \%$ (RSC), respectively (Fig. 3). 
Table 3 Means ( \pm std) of runoff (liters per $\mathrm{m}^{2}$ ) for different mulch cover types (bare soil [BS], rice straw cover [RSC], straw mulch [SC], and wood chips [WCH]) by slope type (cut slope and fill slope), slope gradient (20-25\% and 40-45\%), and road age (3, 10, and 20 years old)

\begin{tabular}{|c|c|c|c|c|c|c|c|c|c|}
\hline \multirow{2}{*}{$\begin{array}{c}\text { Road } \\
\text { age } \\
\text { years }\end{array}$} & $\begin{array}{c}\text { Side } \\
\text { slope }\end{array}$ & \multicolumn{4}{|c|}{ Slope, $20-25 \%$} & \multicolumn{3}{c|}{ Slope, 40-45\% } \\
\cline { 3 - 10 } & BS & RSC & SC & WCH & BS & RSC & SC \\
\hline \multirow{2}{*}{3} & Cut slope & $20.96 \pm 3.34^{\mathrm{Aa}}$ & $17.60 \pm 3.87^{\mathrm{Ab}}$ & $14.85 \pm 2.79^{\mathrm{Ac}}$ & $10.61 \pm 2.47^{\mathrm{Ad}}$ & $29.36 \pm 4.40^{\mathrm{Aa}}$ & $24.91 \pm 5.22^{\mathrm{Ab}}$ & $20.12 \pm 5.50^{\mathrm{Ac}}$ & $13.47 \pm 3.21^{\mathrm{Ad}}$ \\
\cline { 2 - 10 } & Fill slope & $18.73 \pm 3.50^{\mathrm{Ba}}$ & $15.42 \pm 2.99^{\mathrm{Bb}}$ & $12.44 \pm 2.70^{\mathrm{Bc}}$ & $9.13 \pm 2.18^{\mathrm{Bd}}$ & $25.10 \pm 5.35^{\mathrm{Ba}}$ & $21.31 \pm 4.52^{\mathrm{Bb}}$ & $17.54 \pm 3.23^{\mathrm{Bc}}$ & $11.15 \pm 2.72^{\mathrm{Bd}}$ \\
\hline \multirow{2}{*}{10} & Cut slope & $13.72 \pm 3.00^{\mathrm{Aa}}$ & $11.47 \pm 3.25^{\mathrm{Ab}}$ & $10.36 \pm 3.01^{\mathrm{Ac}}$ & $7.89 \pm 2.63^{\mathrm{Ad}}$ & $18.83 \pm 4.02^{\mathrm{Aa}}$ & $15.87 \pm 3.76^{\mathrm{Ab}}$ & $13.39 \pm 4.37^{\mathrm{Ac}}$ & $9.53 \pm 3.59^{\mathrm{Ad}}$ \\
\cline { 2 - 10 } & Fill slope & $11.20 \pm 2.70^{\mathrm{Ba}}$ & $10.09 \pm 3.40^{\mathrm{Bb}}$ & $8.71 \pm 3.77^{\mathrm{Bc}}$ & $7.58 \pm 3.43^{\mathrm{Bd}}$ & $16.10 \pm 3.40^{\mathrm{Ba}}$ & $12.99 \pm 3.46^{\mathrm{Bb}}$ & $10.64 \pm 2.99^{\mathrm{Bc}}$ & $7.42 \pm 2.80^{\mathrm{Bd}}$ \\
\hline \multirow{2}{*}{20} & Cut slope & $8.40 \pm 3.39^{\mathrm{Aa}}$ & $6.75 \pm 3.47^{\mathrm{Ab}}$ & $5.96 \pm 2.75^{\mathrm{Ac}}$ & $4.37 \pm 3.08^{\mathrm{Ad}}$ & $12.58 \pm 3.89^{\mathrm{Aa}}$ & $10.54 \pm 2.26^{\mathrm{Ab}}$ & $8.76 \pm 3.70^{\mathrm{Ac}}$ & $7.10 \pm 3.15^{\mathrm{Ad}}$ \\
\cline { 2 - 10 } & Fill slope & $6.29 \pm 3.55^{\mathrm{Ba}}$ & $5.27 \pm 2.55^{\mathrm{Bb}}$ & $4.32 \pm 2.24^{\mathrm{Bc}}$ & $2.65 \pm 1.28^{\mathrm{Bd}}$ & $9.71 \pm 2.98^{\mathrm{Ba}}$ & $8.29 \pm 3.20^{\mathrm{Bb}}$ & $6.65 \pm 3.57^{\mathrm{Bc}}$ & $4.48 \pm 2.07^{\mathrm{Bd}}$ \\
\hline
\end{tabular}

Values are mean and different letters within each treatment show significant differences $(P<0.05)$

Capital case letters refer to the comparison made among two side slope classes for each mulch treatment and road age class separately (column)

Lower case letters refer to the comparison made among four mulch treatments at each slope category for each side slope class in various road age classes (row)

Table 4 Means ( \pm std) of soil loss $\left(\mathrm{g} \mathrm{m}^{-2}\right.$ ) for different mulch cover types (bare soil [BS], rice straw cover [RSC], straw mulch [SC], and wood chips [WCH]) by slope type (cut slope and fill slope), slope gradient (20-25\% and 40-45\%), and road age (3, 10, and 20 years old)

\begin{tabular}{|c|c|c|c|c|c|c|c|c|c|}
\hline \multirow{2}{*}{$\begin{array}{c}\text { Road } \\
\text { age } \\
\text { years }\end{array}$} & \multirow{2}{*}{$\begin{array}{c}\text { Side } \\
\text { slope }\end{array}$} & \multicolumn{5}{|c|}{ Slope, $20-25 \%$} & \multicolumn{3}{c|}{ Slope, 40-45\% } \\
\cline { 3 - 10 } & BS & RSC & SC & WCH & BS & RSC & SC \\
\hline \multirow{2}{*}{3} & Cut slope & $5.38 \pm 0.55^{\mathrm{Aa}}$ & $4.93 \pm 0.61^{\mathrm{Ab}}$ & $3.85 \pm 0.36^{\mathrm{Ac}}$ & $2.61 \pm 0.35^{\mathrm{Ad}}$ & $6.61 \pm 0.50^{\mathrm{Aa}}$ & $5.45 \pm 0.33^{\mathrm{Ab}}$ & $4.37 \pm 0.26^{\mathrm{Ac}}$ & $3.31 \pm 0.24^{\mathrm{Ad}}$ \\
\cline { 2 - 10 } & Fill slope & $5.07 \pm 0.63^{\mathrm{Ba}}$ & $4.61 \pm 0.59^{\mathrm{Bb}}$ & $3.57 \pm 0.40^{\mathrm{Bc}}$ & $2.11 \pm 0.33^{\mathrm{Bd}}$ & $5.52 \pm 0.27^{\mathrm{Ba}}$ & $4.82 \pm 0.32^{\mathrm{Bb}}$ & $4.04 \pm 0.29^{\mathrm{Bc}}$ & $2.65 \pm 0.25^{\mathrm{Bd}}$ \\
\hline \multirow{2}{*}{10} & Cut slope & $4.87 \pm 0.42^{\mathrm{Aa}}$ & $4.53 \pm 0.41^{\mathrm{Ab}}$ & $3.20 \pm 0.43^{\mathrm{Ac}}$ & $1.84 \pm 0.31^{\mathrm{Ad}}$ & $5.18 \pm 0.24^{\mathrm{Aa}}$ & $4.93 \pm 0.28^{\mathrm{Ab}}$ & $4.17 \pm 0.28^{\mathrm{Ac}}$ & $3.12 \pm 0.17^{\mathrm{Ad}}$ \\
\cline { 2 - 10 } & Fill slope & $4.55 \pm 0.32^{\mathrm{Ba}}$ & $4.29 \pm 0.36^{\mathrm{Bb}}$ & $3.01 \pm 0.26^{\mathrm{Bc}}$ & $1.72 \pm 0.22^{\mathrm{Bd}}$ & $4.74 \pm 0.18^{\mathrm{Ba}}$ & $4.45 \pm 0.20^{\mathrm{Bb}}$ & $3.74 \pm 0.24^{\mathrm{Bc}}$ & $2.42 \pm 0.21^{\mathrm{Bd}}$ \\
\hline \multirow{2}{*}{20} & Cut slope & $3.64 \pm 0.27^{\mathrm{Aa}}$ & $3.25 \pm 0.30^{\mathrm{Ab}}$ & $2.54 \pm 0.28^{\mathrm{Ac}}$ & $1.43 \pm 0.22^{\mathrm{Ad}}$ & $3.97 \pm 0.30^{\mathrm{Aa}}$ & $3.36 \pm 0.21^{\mathrm{Ab}}$ & $2.84 \pm 0.19^{\mathrm{Ac}}$ & $2.29 \pm 0.18^{\mathrm{Ad}}$ \\
\cline { 2 - 10 } & Fill slope & $3.16 \pm 0.24^{\mathrm{Ba}}$ & $2.86 \pm 0.36^{\mathrm{Bb}}$ & $2.21 \pm 0.32^{\mathrm{Bc}}$ & $1.10 \pm 0.18^{\mathrm{Bd}}$ & $3.75 \pm 0.21^{\mathrm{Ba}}$ & $3.31 \pm 0.23^{\mathrm{Bb}}$ & $2.80 \pm 0.22^{\mathrm{Bc}}$ & $1.96 \pm 0.21^{\mathrm{Bd}}$ \\
\hline
\end{tabular}

Values are mean and different letters within each treatment show significant differences $(P<0.05)$

Capital case letters refer to the comparison made among two side slope classes for each mulch treatment and road age class separately (column)

Lower case letters refer to the comparison made among four mulch treatments at each slope category for each side slope class in various road age classes (row)

Table 5 Mean relative change in surface runoff volume (\%) by slope gradient ( $20-25 \%$ and $40-45 \%)$ and road age $(3,10$, and 20 years old). Relative change was determined as changes between cut slope and fill slope in each mulch type treatment (rise straw cover [RSC], straw cover [SC], wood chips [WCH], and bare soil [BS])

\begin{tabular}{|c|c|c|c|c|c|}
\hline \multirow{2}{*}{$\begin{array}{c}\text { Road age } \\
\text { years }\end{array}$} & \multirow{2}{*}{$\begin{array}{c}\text { Slope gradient } \\
\%\end{array}$} & \multicolumn{4}{|c|}{ Mulch type } \\
\cline { 3 - 6 } & & BS & RSC & SC & WCH \\
\hline \multirow{2}{*}{3} & $20-25$ & 11.9 & 14.1 & 19.4 & 16.2 \\
\cline { 2 - 6 } & $40-45$ & 17.0 & 16.9 & 14.7 & 20.8 \\
\hline \multirow{2}{*}{10} & $20-25$ & 22.5 & 13.7 & 18.9 & 4.1 \\
\cline { 2 - 6 } & $40-45$ & 17.0 & 22.2 & 25.9 & 28.5 \\
\hline \multirow{2}{*}{20} & $20-25$ & 24.8 & 28.1 & 38.1 & 64.6 \\
\cline { 2 - 6 } & $40-45$ & 29.6 & 27.1 & 31.7 & 58.5 \\
\hline
\end{tabular}

Table 6 Mean relative change in soil loss (\%) by slope gradient $(20-25 \%$ and $40-45 \%)$ and road age $(3,10$, and 20 years old). Relative change was determined as changes between cut slope and fill slope in each mulch type treatment (rise straw cover [RSC], straw cover [SC], wood chips [WCH], and bare soil [BS])

\begin{tabular}{|c|c|c|c|c|c|}
\hline \multirow{2}{*}{$\begin{array}{c}\text { Road age } \\
\text { years }\end{array}$} & \multirow{2}{*}{$\begin{array}{c}\text { Slope gradient } \\
\%\end{array}$} & \multicolumn{4}{|c|}{ Mulch type } \\
\cline { 3 - 6 } & & BS & RSC & SC & WCH \\
\hline \multirow{2}{*}{3} & $20-25$ & 6.2 & 6.9 & 8.0 & 24.2 \\
\cline { 2 - 6 } & $40-45$ & 198 & 13.2 & 8.2 & 25.0 \\
\hline \multirow{2}{*}{10} & $20-25$ & 7.1 & 5.8 & 6.5 & 7.2 \\
\cline { 2 - 6 } & $40-45$ & 9.2 & 10.8 & 11.5 & 28.6 \\
\hline \multirow{2}{*}{20} & $20-25$ & 14.7 & 13.7 & 14.8 & 29.8 \\
\cline { 2 - 6 } & $40-45$ & 5.9 & 1.5 & 1.6 & 16.6 \\
\hline
\end{tabular}


A. Solgi et al. Evaluating the Effectiveness of Mulching for Reducing Soil Erosion in Cut Slope and Fill Slope... (259-268)

Slope $20-25, \% \quad$ Slope $40-45, \%$

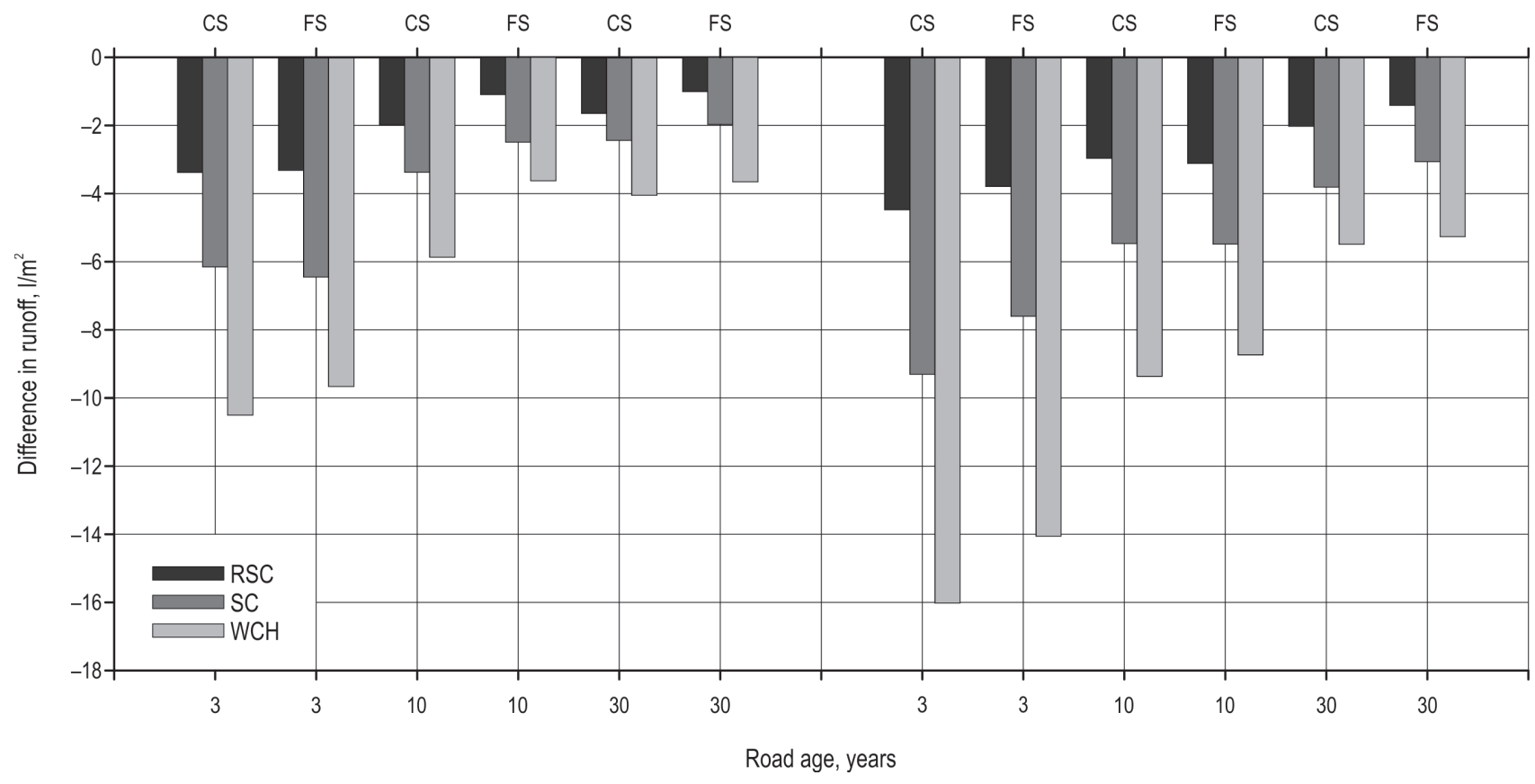

Fig. 2 Average difference in surface runoff volume (liters per $\mathrm{m}^{2}$ ) in plots covered with rice straw (RSC), sawdust (SC), and wood chips (WCH) relative to control treatment (bare soil) in cut slopes (CS) and fill slopes (FS) for slope gradients 20-25\% (left) and 40-45\% (right)

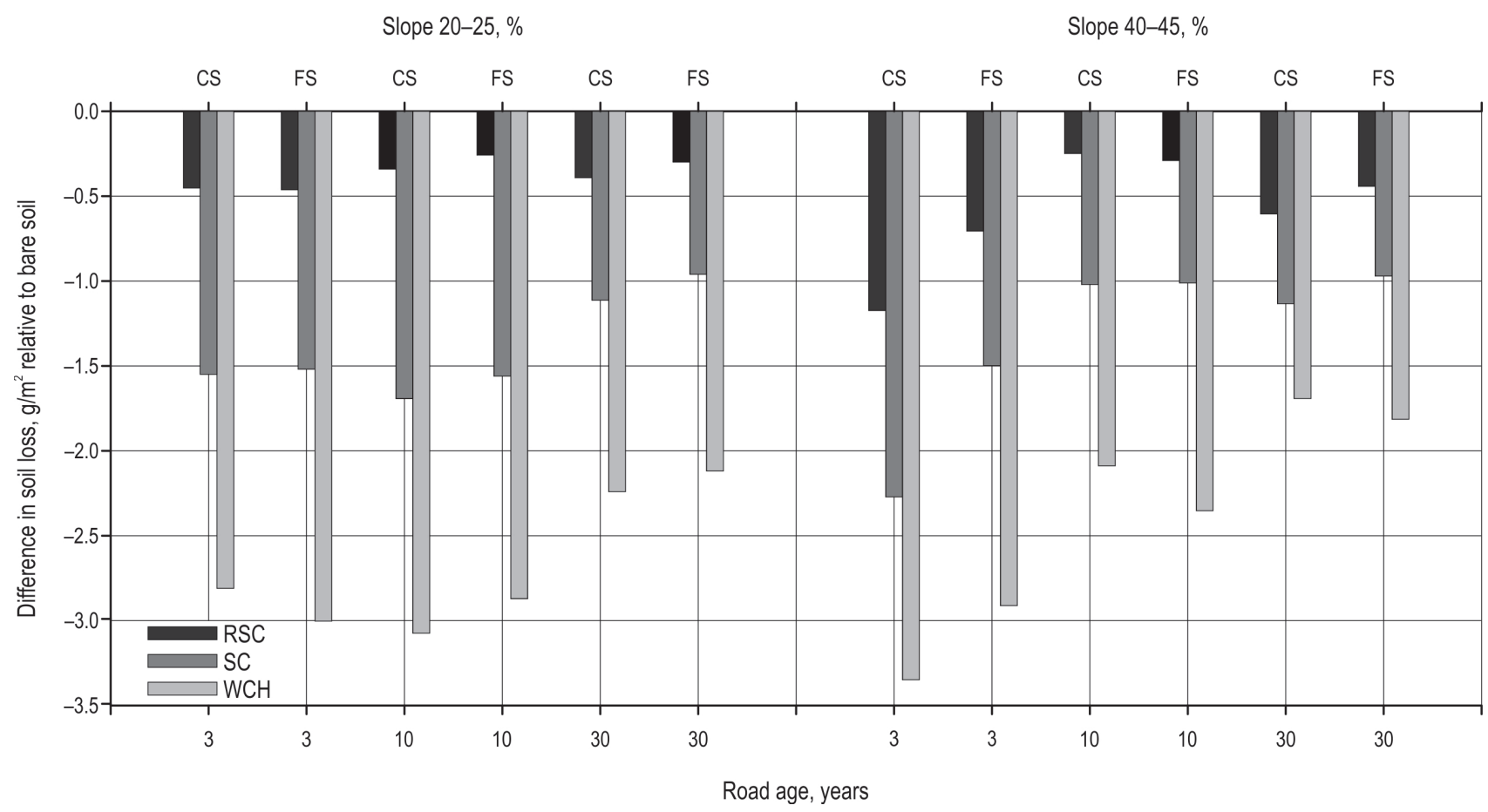

Fig. 3 Average difference in soil loss $\left(\mathrm{g} \mathrm{m}^{-2}\right.$ ) in plots covered with rice straw (RSC), sawdust (SC), and wood chips (WCH) relative to control treatment (bare soil) in cut slopes (CS) and fill slopes (FS) for slope gradients 20-25\% (left) and 40-45\% (right) 


\section{Discussion}

Although a natural process, soil erosion is one of the most critical environmental problems worldwide (e.g. Le Roux et al. 2008, Schönbrodt-Stitt et al. 2013, Ma et al. 2014, Seutloali and Beckedahl 2015a) that has been accelerated across the landscape through agriculture, mining, grazing, and fire activities (Leh et al. 2013, Mandal and Sharda 2013, Ziadat and Taimeh 2013). As road construction typically modifies natural hill-slope profiles, the construction of cut slopes and fill slopes and the creation of impervious roadbeds can concentrate runoff (Jordán-López and Martinez-Zavala 2008, Seutloali and Beckedahl 2015b), potentially resulting in soil degradation and landform changes (Cerdà 2007, Cheng et al. 2013).

Adverse effects of runoff and soil loss along forest roads can be highly variable but they are more severe on steeper slopes and on cut slopes compared to fill slopes in this study. However, regardless of slope gradient on both cut and fill slopes, adverse effects could be lessened by the application of different types of mulch covers. On both types of side slope and for all mulch cover types and road ages, the amounts of runoff and soil loss increased consistently with increasing slope gradients, with greatest amounts observed on cut slopes on bare soils (controls) on gradients of $40-45 \%$, and smallest amounts observed on fill slopes covered with wood chips on gradients of $20-25 \%$, regardless of road age. These results confirm previous findings of a considerable impact of increasing cut slope and fill slope gradients on erosion (Solgi et al. 2014, Solgi et al. 2019). The drastic increase in absolute amounts of runoff and relative rates of soil loss on bare soil and slope gradients of $40-45 \%$ is most likely due to the reduced surface roughness on bare soils and the greater velocity of surface water on steeper slopes that increases the detachment and transport of soil particles (Chaplot and Le Bissonnais 2000) and enhances the erosive power of the water (Ekwue and Harrilal 2010). Measured rates of soil loss on bare soil (control) on cut slopes, which were 1.11 times greater than the loss on fill slopes, highlight the importance of carrying out protective operations, particularly on cut slopes. These findings echo previous reports of soil loss that was twice as high on cut slopes as on road surface and six times as high on cut slopes as on fill slopes (Lotfalian et al. 2013), and this may be due to the fact that cut slopes eroded principally because soils can be loosened by diurnal cycles of freezing and thawing in winter, whereas soil loss from fill slopes often slip when soils are wet in early spring (Swift 1984). Indeed, because cut slopes are particularly vulnerable to soil loss, being up to ten times more erodible than fill slopes (Riley 1988, see also Hacisalihoğlu et al. 2019, Jordan and Martinez-Zavala
2008 but not Turk 2018), one way to minimize erosion is to locate roads on ridges and gentle slopes to avoid the need for cut slopes (Morgan 2005).

Where roads cannot be placed into more gentle terrain, the use of mulch of wood chips, sawdust and straw is an effective method to reduce or prevent runoff and soil loss on forest roads (Wade et al. 2012, Masumian et al. 2017, Lotfalian et al. 2019), especially on cut slopes. In addition, mulch maintains soil moisture and improves soil fertility and health (Lotfalian et al. 2019, Solgi et al. 2019). Of five closure treatments of bladed skid trails (i.e., water bar only (bare soil); water bar and grass seed; water bar, grass seed, and straw mulch; water bar and piled hardwood brush; water bar and piled softwood brush) in the Piedmont of Virginia, the highest erosion rate was observed on water bars (bare soil), while the lowest erosion rate occurred under the mulch treatment (Wade et al. 2012). Similarly, the application of cover with jute or mulch reduced soil erosion over bare soil (cut slope), with lowest erosion rates under jute (Lotfalian et al. 2019), because this application provides immediate protection of the bare soil from the physical impacts of raindrops by reducing the velocity of surface runoff that can loosen soil particles and enhancing infiltration and deposition of sediment (Puustinen et al. 2005). Closure treatments that increase the surface roughness and the interception of raindrops are thus very effective in delaying runoff generation (Jordán et al. 2010).

Cover of wood chips was more effective than sawdust mulch, straw mulch, and bare soil for reducing surface runoff volume and sediment yield on all three road age classes on both cut and fill slopes. Wood chips decreased runoff on cut slopes and fill slopes by $49 \%$ and $51 \%$, respectively, and sediments by $51 \%$ and $55 \%$, respectively, compared to bare soil, which is similar to the $51 \%$ reduction in soil loss after an application of wood chips reported by Kim et al. (2008). Respective decreases on cut slopes and fill slopes for other cover types were smaller, but still reduced runoff volumes between 30-31\% (sawdust mulch), and 16\% (straw mulch) and sediment yields by 28-29\% (sawdust mulch), and 9-11\% (straw mulch) over bare soil. This confirms that wood chips are an effective means to decrease sediment yields that even outperform sawdust and straw mulch (Turk 2018) and this is likely due to the resistance of wood-based materials to being transported away by runoff and a longer persistence than straw mulch (Foltz 2012). This makes woodbased mulches very effective in erosion control and runoff mitigation (Foltz and Dooley 2003, Yanosek et al. 2006, Foltz and Copeland 2009, Foltz 2012), even though the amount of effective ground cover provided by mulch may even be more important than the type of mulch (Foltz 2012). 
Finally, results of this study of diminishing runoff and soil loss with road age are consistent with reports of a temporal effect of various mulch treatments on runoff and soil loss (e.g., Grace 1999, Sidle et al. 2004). Although we did not assess the natural plant cover in the cutslope and fillslope in the summer prior to this study, native vegetation that may have taken root in cutslopes and fillslopes would have led to a substantial reduction in runoff and soil loss over time (Grace 1999), which may explain why runoff and soil loss diminished with road age even on bare soil. Although the absolute amounts of runoff and soil loss declined in all treatments with road age, the application of mulch reduced these absolute amounts relative to bare soil independent of road age (Fig. 2 and 3). The relative magnitude, for example, of the reduction in runoff and sediment yield following the application of wood chips compared to bare soil was between $40-60 \%$ in cutslopes and fillslopes regardless of road age, indicating that these treatments appear effective even 20 years after a forest road was built. Nonetheless, it appears that these mulch treatments are most effective if they are applied early and become an essential part of road construction in the first place.

\section{Conclusions}

The application of mulch and slash to cover forest road segments can effectively reduce soil loss following road construction. On steep side slopes and especially on cut slopes, where soil erosion rates are very high, mulch can enhance soil stability. The effectiveness of mulch treatments is primarily due to providing ready ground cover in the form of mulch, which stabilizes the soil by providing protection from the impact of rainfall, thus reducing overland flow velocity through increased surface roughness. Rice straw mulch provided less effective soil protection than woody chips and sawdust mulch due to less weight, which can result in more convenient transfer and finally less cover. As soils are highly susceptible to erosion right after a disturbance (Sidle et al. 2004), as evidenced in declining surface runoff and soil loss with increasing road age in this study, we conclude that mulch should be applied immediately after the road construction is completed. More severe negative effects of road construction on soil physical properties and surface erosion and sediment yields on side slope segments (particularly cut slopes) of forest roads, indicate the need for immediate attention to minimize adverse effects. While absolute amounts of surface runoff and sediment yields were lowest on older roads that have been subjected to these processes for many years, the application of mulch was still effective even on these older roads.

\section{References}

Arnaez, J., Larrea, V., Ortigosa, L., 2004: Surface runoff and soil erosion on unpaved forest roads from rainfall simulation tests in northeastern Spain. Catena 57(1): 1-14. https://doi. org/10.1016/j.catena.2003.09.002

Bochet, E., García-Fayos, P., 2004: Factors Controlling Vegetation Establishment and Water Erosion on Motorway Slopes in Valencia, Spain. Restoration Ecology 12(2): 166-174. https://doi. org/10.1111/j.1061-2971.2004.0325.x

Bochet, E., García-Fayos, P., Tormo, J., 2009: How can we control erosion of roadslopes in semiarid Mediterranean areas? Soil improvement and native plant establishment. Land Degradation and Development 21(2): 110-121. https://doi.org/10.1002/ ldr.911

Cerdà, A., 2007: Soil water erosion on road embankments in eastern Spain. Science of the Total Environment 378(1-2): 151155. https://doi.org/10.1016/j.scitotenv.2007.01.041

Chaplot, V., Le Bissonnais, Y., 2000: Field measurements of interrill erosion under different slopes and plot sizes. Earth Surface Processes and Landforms 25(2): 145-153. https://doi.org/10.1002/ (SICI)1096-9837(200002)25:2<145::AID-ESP51>3.0.CO;2-3

Cheng, B., Lv, Y., Zhan, Y., Su, D., Cao, S., 2015: Constructing China's roads as works of art: a case study of »esthetic greenway" construction in the Shennongjia region of China. Land Degradation and Development 26(7): 324-330. https://doi. org/10.1002/ldr.2210

Ekwue, E.I., Harrilal, A., 2010: Effect of soil type, peat, slope, compaction effort and their interactions on infiltration, runoff and raindrop erosion of some Trinidadian soils. Biosystem Engineering 105(1): 112-118. https://doi.org/10.1016/j.biosystemseng.2009.10.001

FAO, Food and Agriculture Organization of the United Nations, 2015: World reference base for soil resources 2014, International soil classification system for naming soils and creating legends for soil maps (Update 2015), World Soil Resources Reports 105, Food and Agriculture Organization of the United Nations, Rome, Italy.

Foltz, R.B., Dooley, J.H., 2003: Comparison of erosion reduction between wood stands and agricultural straw. Transactions of the American Society of Agricultural Engineers 46(5): 13891396. https://doi.org/10.13031/2013.15450

Foltz, R.B., Copeland, N.S., 2009: Evaluating the efficacy of wood shreds for mitigating erosion. Journal of Environmental Management 90(2): 779-785. https://doi.org/10.1016/j.jenvman.2008.01.006

Foltz, R.B., 2012: A comparison of three erosion control mulches on decommissioned forest road corridors in the northern Rocky Mountains, United States. Journal of Soil and Water Conservation 67(6): 536-544. https://doi.org/10.2489/jswc.67.6.536

Grace, J.M.III., 1999: Erosion control techniques on forest road cutslopes and fillslopes in North Alabama. In Proc. Seventh International Conference on Low-Volume Roads: Volume 2. Transportation Research Record 1652, 227-234. Washington, D.C.: National Research Council, Transportation Research Board.

Hacisalihoğlu, S., Gümüş, S., Kezik, U., Karadağ, H., 2019: Impact of Forest Road Construction on Topsoil Erosion and Hydro-Physical Soil Properties in a Semi-Arid Mountainous Ecosystem in Turkey. Polish Journal of Environmental Studies 28(1): 113-121. https://doi.org/10.15244/pjoes/81615 
Jordán-López, A., Martinez-Zavala, L., 2008: Soil loss and runoff rates on unpaved forest roads in southern Spain after simulated rainfall. Forest Ecology and Management 255(3-4): 913-919. https://doi.org/10.1016/j.foreco.2007.10.002

Jordán-López, A., Martínez-Zavala, L., Bellinfante, N., 2009: Impact of different parts of unpaved forest roads on runoff and sediment yield in a Mediterranean area. Science of the Total Environment 407(2): 937-944. https://doi.org/10.1016/j.scitotenv.2008.09.047

Kalra, Y.P., Maynard, D.G., 1991: Methods and manual for forest soil and plant analysis. Northern Forestry Centre NORX-319, Forestry Canada, Northwest Region, Edmonton, Alberta, Canada.

Kim, C.G., Shin, K., Joo, K.Y., Lee, K.S., Shin, S.S., Choung, Y., 2008: Effects of soil conservation measures in a partially vegetated area after forest fires. Science of the Total Environment 399(1-3): 158-164. https://doi.org/10.1016/j.scitotenv.2008.03.034

Leh, M., Bajwa, S., Chaubey, I., 2013: Impact of land use change on erosion risk: an integrated remote sensing, geographic information system and modeling methodology. Land Degradation and Development 24(5): 409-421. https://doi.org/10.1002/ ldr.1137

Le Roux, J.J., Morgenthal, T.L., Malherbe, J., Pretorius, D.J., Sumner, P.D., 2008: Water erosion prediction at a national scale for South Africa. Water SA. 34(3): 305-314.

Li, X.H., Zhang, Z.Y., Yang, J., Zhang, G.H., Wang, B., 2011: Effects of Bahia grass cover and mulch on runoff and sediment yield of sloping red soil in Southern China. Soil Science Society of China 21(2): 238-243. https://doi.org/10.1016/S10020160(11)60123-9

Liu, Y.J., Wang, T.W., Cai, C.F., Li, Z.X., Cheng, D.B., 2014: Effects of vegetation on runoff generation, sediment yield and soil shear strength on road-side slopes under a simulation rainfall test in the Three Gorges Reservoir Area, China. Science of the Total Environment 485-486(1): 93-102. https://doi.org/10.1016/j. scitotenv.2014.03.053

Lotfalian, M., Parsakhoo, A., Kavian, A., Hosseini, S.A., 2013: Runoff and sediment concentration of different parts of a road in Hyrcanian forests. Forest Science Practices 15(2): 144-151. https://doi.org/10.1007/s11632-013-0212-z

Lotfalian, M., Babadi, T.Y., Akbari, H., 2019: Impacts of soil stabilization treatments on reducing soil loss and runoff in cutslope of forest roads in Hyrcanian forests. Catena 172(1): 158-162. https://doi.org/10.1016/j.catena.2018.08.023

Ma, X., He, Y., Xu, J., Van Noordwijk, M., Lu, X., 2014: Spatial and temporal variation in rainfall erosivity in a Himalayan watershed. Catena 121(1): 248-259. https://doi.org/10.1016/j.catena.2014.05.017

Mandal, D., Sharda, V., 2013: Appraisal of soil erosion risk in the eastern Himalayan region of India for soil conservation planning. Land Degradation and Development 24(5): 430-437. https://doi.org/10.1002/ldr.1139

Masumian, M., Naghdi, R., Zenner, E.K., 2017: Effectiveness of water diversion and erosion control structures on skid trails following timber harvesting. Ecological Engineering 105(2): 370-378. https://doi.org/10.1016/j.ecoleng.2017.05.017

McBroom, M.W., Beasley, R.S., Chang, M., Ice, G.G., 2008: Water quality effects of clearcut harvesting and forest fertilization with best management practices. Journal of Environmental Quality 37(1): 114-124. https://doi:10.2134/jeq2006.0552
Morgan, R.P.C., 2005: Soil erosion and conservation. Third edition, Blackwell Publishing, Malden, MA, USA, 304 p.

Puustinen, M., Koskiaho, J., Peltonen, K., 2005: Influence of cultivation methods on suspended solids and phosphorus concentrations in surface runoff on clayey sloped fields in boreal climate. Agriculture, Ecosystems, and Environment 105(4): 565-579. https://doi.org/10.1016/j.agee.2004.08.005

Riley, S.J., 1988: Soil loss from road batters in the Karuah State Forest, eastern Australia. Soil Technology 1(4): 313-332. https:// doi.org/10.1016/0933-3630(88)90012-8

Sadeghi, S.H.R., Ghaderi Vangah, B., Safaeeian, N.A., 2007: Comparison between effects of open grazing and manual harvesting of cultivated summer rangelands of northern Iran on in filtration, runoff and sediment yield. Land Degradation and Development 18(6): 608-620. https://doi.org/10.1002/ldr.799

Schönbrodt-Stitt, S., Bosch, A., Behrens, T., Hartmann, H., Shi, X., Scholten, T., 2013: Approximation and spatial regionalization of rainfall erosivity based on sparse data in a mountainous catchment of the Yangtze River in Central China. Environmental Science and Pollution Research 20(3): 6917-6933. https://doi. org/10.1007/s11356-012-1441-8

Seutloali, K.E., Beckedahl, H.R., 2015a: Understanding the factors influencing rill erosion on roadcuts in the south eastern region of South Africa. Solid Earth 6(2): 633-641. https://doi. org/10.5194/se-6-633-2015

Seutloali, K.E., Beckedahl, H.R., 2015b: Review of road-related soil erosion: an assessment of causes, evaluation techniques and available control measures. Earth Sciences Research Journal 19(1): 73-80. http://dx.doi.org/10.15446/esrj.v19n1.43841

Shao, Q., Gu, W., Dai, Q.Y., Makoto, S., Liu, Y., 2014: Effectiveness of geotextile mulches for slope restoration in semi-arid northern China. Catena 116(1): 1-9. https://doi.org/10.1016/j. catena.2013.12.006

Sidle, R.C., Sasaki, S., Otsuki, M., Noguchi, S., Abdul Rahim, N., 2004: Sediment pathways in a tropical forest: effects of logging roads and skidtrails. Hydrological Process 18(4): 703-720. https://doi.org/10.1002/hyp.1364

Solgi, A., Najafi, A., Sadeghi, S.H., 2014: Effects of traffic frequency and skid trail slope on surface runoff and sediment yield. International Journal of Forest Engineering 25(2): 171-178. https://doi.org/10.1080/14942119.2014.955699

Solgi, A., Naghdi, R., Labelle, E.R., Behjou, F.K., Hemmati, V., 2019: Evaluation of different methods for erosion control on bladed machine operating trails. Croatian Journal of Forest Engineering 40(2): 319-326. https://doi.org/10.5552/crojfe.2019.532 Swift, L.Jr., 1984: Soil losses from roadbeds and cut and fill slopes in the Southern Appalachian Mountains. Southern Journal of Applied Forestry 8(4): 209-216. https://doi.org/10.1093/ sjaf/8.4.209

Swift, L.Jr., Burns, R., 1999: The three Rs of roads: redesign, reconstruction, and restoration. Journal of Forestry 97(8): 40-44. https://doi.org/10.1093/jof/97.8.40

Turk, Y., 2018: The effects of using wood chips and slash in reducing sheet erosion on forest road slopes. Forests 9(11): 712721. https://doi.org/10.3390/f9110712

Wade, C.R., Bolding, M.C., Aust, W.M., Lakel, W.A., 2012: Comparison of five erosion control techniques for bladed skid trails in Virginia. Southern Journal of Applied Forestry 36(4): 191-197. https://doi.org/10.5849/sjaf.11-014 
Yanosek, K.A., Foltz, R.B., Dooley, J.H., 2006: Performance assessment of wood strand erosion control materials among varying slopes, soil textures, and cover amounts. Journal of Soil and Water Conservation 61(2): 45-51.

Zar, J.H., 1999: Biostatistical Analysis. $4^{\text {th }}$ Ed. Upper Saddle River, Prentice Hall, 663 p.

Ziadat, F., Taimeh, A., 2013: Effect of rainfall intensity, slope, land use and antecedent soil moisture on soil erosion in an arid environment. Land Degradation and Development 24(6): 582590. https://doi.org/10.1002/ldr.2239

Ziegler, A.D., Giambelluca, T.W., Sutherland, R.A., Nullet, M.A., Yarnasarn, S., Pinthong, J., Preechapanya, P., Jaiaree, S., 2004: Toward understanding the cumulative impacts of roads in upland agricultural watersheds of northern Thailand. Agriculture, Ecosystems and Environment 104(1): 145-158. https://doi. org/10.1016/j.agee.2004.01.012

(c) 2021 by the authors. Submitted for possible open access publication under the terms and conditions of the Creative Commons Attribution (CC BY) license (http://creativecommons.org/licenses/by/4.0/).

Authors' address:

Ahmad Solgi, PhD

e-mail: aforestsolgi@gmail.com

Prof. Ramin Naghdi, PhD

e-mail: rnaghdi@guilan.ac.ir

University of Guilan

Faculty of Natural Resources

Department of Forestry

Sowmeh Sara, Guilan

P.O. Box 1144

IRAN

Eric K. Zenner

e-mail: eric.zenner@psu.edu

Penn State University

Department of Ecosystem Science, and Management University Park, PA

USA

Assist. prof. Vahid Hemmati, PhD

e-mail: vahidhemmatiliau@gmail.com

Islamic Azad University

Lahijan Branch

IRAN

Prof. Farshad Keivan Behjou, PhD

e-mail: farshad.keivan@gmail.com

University of Mohaghegh Ardabili

Faculty of Agricultural Technology

and Natural Resources

Department of Forestry and Forest Economies

Ardabil

IRAN

Assist. prof.Ali Masumian, PhD

e-mail: masumian.class@gmail.com

Faculty Member at University of

Applied Science and Technology

Tehran 1193653471

Received: September 26, 2019

IRAN

Accepted: July 13, 2020

* Corresponding author 